TITLE:

\title{
Human Mesenchymal Stem Cell Therapy for Acute Graft Versus Host Disease
}

\section{$\operatorname{AUTHOR}(\mathrm{S}):$}

Yoshioka, Satoshi; Miura, Yasuo

\section{CITATION:}

Yoshioka, Satoshi ... [et al]. Human Mesenchymal Stem Cell Therapy for Acute Graft Versus Host Disease. Translational Medicine 2016, 6(3): 1000171.

ISSUE DATE:

2016-02-25

URL:

http://hdl.handle.net/2433/218413

\section{RIGHT:}

(C) 2016 Yoshioka S, et al. This is an open-access article distributed under the terms of the Creative Commons Attribution License, which permits unrestricted use, distribution and reproduction in any medium, provided the original author and source are credited. 


\title{
Human Mesenchymal Stem Cell Therapy for Acute Graft Versus Host Disease
}

\section{Satoshi Yoshioka ${ }^{1^{*}}$ and Yasuo Miura ${ }^{2}$}

1Department of Hematology, Kobe City Medical Center General Hospital, Japan

2Department of Transfusion Medicine and Cell Therapy, Kyoto University Hospital, Kyoto, Japan

"Corresponding author: Satoshi Yoshioka, Department of Hematology, Kobe City Medical Center General Hospital, Kobe 650-0047, Japan, Tel: +81-783024321; Fax: +81-783027537; E-mail: satoseay@kcho.jp

Received date: April 14, 2016; Accepted date: April 19, 2016; Published date: May 25, 2016

Copyright: ( 2016 Yoshioka S, et al. This is an open-access article distributed under the terms of the Creative Commons Attribution License, which permits unrestricted use, distribution and reproduction in any medium, provided the original author and source are credited.

\begin{abstract}
Acute graft versus host disease (GVHD) is the most critical complication after allogeneic hematopoietic stem cell transplantation (allo-HSCT). The understanding of major histocompatibility complex (MHC) and the development of acute GVHD prophylaxis have contributed to decreasing the incidence of severe acute GVHD. However, these progresses expand the chance of receiving allo-HSCT from human leukocyte antigen (HLA) mismatched donor. In addition, the expanding of indication for allo-HSCT to elderly patients or patients with organ dysfunction by the pervasiveness of reduced-intensity conditioning is associated with increased risk of acute GVHD. Unexpectedly, severe refractory acute GVHD can occur even in allo-HSCT from HLA matched sibling donor. The first line therapy for severe acute GVHD is corticosteroid, but the second line therapy has not been established and the prognosis of steroid-resistant acute GVHD remains poor. Recently, the efficacy of human bone marrow mesenchymal stem cell (MSC) therapy for steroid-resistant acute GVHD has been consistently reported. MSCs are approved as a cell therapy drug for steroid-resistant acute GVHD in some countries. We here review the history and the future of MSC therapy for acute GVHD.
\end{abstract}

Keywords: Mesenchymal stem cell; Immunomodulation; Graft versus host disease; Hematopoietic stem cell transplantation

\section{Introduction}

Although the development of molecular-targeted therapies has improved prognosis of hematopoietic malignancies for the last couple of decades, allogeneic hematopoietic stem cell transplantation (alloHSCT) remains the only therapeutic approach to relapsed/refractory diseases. The development of supportive cares for many complications like infectious diseases and graft versus host disease (GVHD) has remarkably improved the outcomes of allo-HSCT [1]. However, severe acute GVHD that occurres within the first 100 days after allo-HSCT is one of the most critical problems. The frequency and severity of acute GVHD differ depending on HSC source, human leukocyte antigen (HLA) disparity, conditioning regimen, acute GVHD prevention, and comorbidities [2]. The development of GVHD prophylaxis and reduced-intensity conditioning expanded the chance of receiving alloHSCT, but the frequency of refractory severe acute GVHD definitely increased. A lot of novel drugs, such as anti-thymocyte immunoglobulin, mycophenolate mofetil, infliximab, have been used for steroid-resistant acute GVHD. Response rate of these drugs has been reported to be about 50\% (complete response; about 10-30\%) and median overall survival after treatment less than 1 year [3].

Mesenchymal stem cells (MSCs) were discovered as fibroblastic cells to differentiate to osteo-progenitor cells by Freidenstein et al. [4]. Pittenger et al. indicated that MSCs existed in human bone marrow [5]. Definition of human MSC includes adherence to plastic dish, expression of CD105, CD73 and CD90, lack of expression of CD45, CD34, CD14 or CD11b, CD79a or CD19 and HLA-DR and differentiation to osteoblast, adipocyte, and chondroblast in vitro [6].
MSCs are isolated from several tissues including bone marrow, fatty tissue, and umbilical cord with standard adherent method, and these cells include a heterogeneous cell population. MSCs have immunomodulatory potential as well as multi-differentiation potential. MSCs and their progenies support hematopoiesis as niche components in bone marrow [7,8]. MSCs are most currently investigated as a cell therapy source because of their accessibility and multipotency [9]. MSC therapy for steroid-resistant acute GVHD has achieved the most attractive results. In this review we describe the potential and problems of MSC therapy.

\section{Immunomodulatory function of MSCs}

MSC therapy for acute GVHD exploits the immunomodulatory properties of MSCs. The immunomodulatory effect of MSCs was first indicated by long term engraftment in a xenogeneic environment in 2000 [10]. Although its mechanisms have not been fully understood, previous studies have revealed that MSCs inhibited the function of immune cells via cell to cell contact dependent mechanism and several soluble immune modulators [11-14].

MSCs can suppress the proliferation of naïve $T$ cells as well as activated $\mathrm{CD} 4+$ helper $\mathrm{T}(\mathrm{Th})$ and $\mathrm{CD} 8+$ cytotoxic $\mathrm{T}$ cells regardless of major histocompatibility complex (MHC) restriction $[15,16]$. MSCs decrease interferon (IFN) $-\gamma$ production from Th1 cells and interleukin (IL)- 4 production from Th 2 cells. The immunosuppressive effect is considered to keep $\mathrm{T}$ cells in the G0/G1 cell cycle phase via the downregulation of cyclin D2 expression [17]. MSCs do not expressed MHC class II and co-stimulatory molecules such as CD40, CD80, and CD86 $[5,16]$, which may relate with T cell anergy. MSCs inhibit Th17 cells proliferation and IL-17 production [18]. MSCs can expand regulatory $\mathrm{T}$ cells, which are thought to inhibit allogeneic lymphocyte 
Citation: Yoshioka S, Miura Y (2016) Human Mesenchymal Stem Cell Therapy for Acute Graft Versus Host Disease. Transl Med (Sunnyvale) 6:

Page 2 of 6

proliferation [19]. MSCs can also suppress the proliferation and IFN- $\gamma$ production of natural killer cells [20]. MSCs have been shown to inhibit the proliferation, immunoglobulin production and chemokine secretion of activated B cell proliferation [21]. The differentiation from monocytes or hematopoietic cells to dendritic cells (DCs) and the maturation of DCs can be impaired by MSCs [22]. In contrast, MSCs can promote the differentiation to M2 macrophages which abundantly produce IL-10 [13]. These modulations of immune cells are associated with many soluble factors released from MSCs, including transforming growth factor- $\beta 1$, hepatocyte growth factor, IL-10, indoleamine 2, 3dioxygenase, prostaglandin E2, nitric oxide, matrix metalloproteinases, HLA-G (Figure 1) [11-14]. The secretion of these factors from MSCs has been shown to be induced by IFN- $\gamma$ alone, or in combination with tumor necrosis factor (TNF)- $\alpha$, IL-1 $\alpha$, or IL-1 $\beta$ [23]. Toll-like receptors (TLR) also have been reported to be expressed on MSCs and to trigger the induction of cytokines and chemokines [24]. Thus, various and complicated mechanisms are involved with immunomodulatory properties of MSCs.

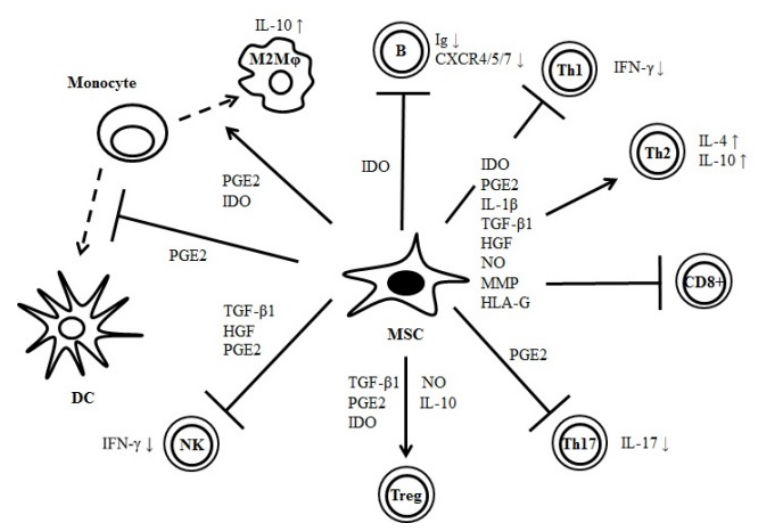

Figure 1: Interactions between MSCs and immune cells. MSC inhibits the proliferation, immune response and cytokine production of B cell (B), Th1 cell, CD8+ cell (Th1), Th17 cell (Th17), and NK cell (NK). In contrast, MSC promotes the production of IL-4 and IL-10 from Th2 cell (Th2), and the expansion of regulatory $\mathrm{T}$ cell (Treg). These responses are induced via soluble factors inclduing hepatocyte growth factor (HGF), indoleamine 2, 3-dioxygenase (IDO), IFN- $\gamma$, IL-4, IL-10, nitric oxide (NO), prostaglandin E2 (PGE2) and transforming growth factor- $\beta 1$ (TGF- $\beta 1$ ). CD8+ cytotoxic T cell; CD8+, M2 macrophage; $\mathrm{M} 2 \mathrm{M} \varphi$, dendritic cell; DC.

In addition, little immunogenicity of low expression level of MHC class I molecule and absence of class II molecules contributes to be immunomodulatory phenotype [25]. The characteristics allow MSC therapy from third party donors for acute GVHD. However, the production of allo-reactive antibodies to MSCs and the rejection of transplanted MSCs have described [26]. Long term persistence of MSCs was not observed after HSCT and high-dose MSCs transplantation for children with severe osteogenesis imperfecta [27]. Thus, whether MSCs derived from third party donor is appropriate remains controversial.

\section{Clinical studies of MSC therapy for refractory acute GVHD using individual donors}

The first success of MSC therapy for acute GVHD was reported by Le Blanc et al. in 2004 [28]. A 9-year-old boy with acute lymphoblastic leukemia who received allo-HSCT from an unrelated donor suffered from grade IV acute GVHD, though he was treated with steroid pulse therapy, extracorporeal PUVA, infliximab, decritumab, mycophenolate mofetil, and methotrexate. MSCs at a dose of $2 \times 106$ cells $/ \mathrm{kg}$ isolated from bone marrow of a haploidentical donor, his mother, were administered to him. His acute GVHD was rapidly improved within a week after MSC therapy. Following the amazing result, Le Blanc et al. conducted a multi-institutional joint phase II experimental study of MSC therapy for steroid-resistant severe acute GVHD [29]. Thirty of 55 patients with steroid-resistant acute GVHD (grade II, $\mathrm{n}=5$; grade III, $\mathrm{n}=25$; grade IV, $\mathrm{n}=25$ ) achieved CR complete response (CR) just 3-63 days (median, 18 days) after MSC therapy. Surprisingly, $90 \%$ of them achieved CR with only a single MSC administration. Both donor type and cell dose were not associated with overall response. Severity of acute GVHD also had no significant effect on response. Two-year overall survival in the patients with CR $(52 \%, 95 \% \mathrm{CI} ; 34-70 \%)$ was better than that in the patients with PR or no response $(16 \%, 95 \% \mathrm{CI}$; $0-32 \%, p=0.018$ ). Subsequently, many studies of MSC therapy for refractory acute GVHD have been conducted until now (summarized in Table 1) [29-37]. MSCs were mostly derived from third party donors in all the studies. Median administered dose of MSCs were 1-2 $\times 106$ cells $/ \mathrm{kg}$ and median number of doses was 1 to 3 . Response was rapidly observed in responders. CR rate (8-65\%) and overall response rate (16-86\%) were varied, which were far superior to conventional salvage treatment for steroid resistant acute GVHD. Overall survival in the responders was significantly better compared to non-responders as reported by Le Blanc. In the three reports containing both pediatric and adult patients, response in pediatric patients was significantly superior to that in adult patients [29,35,36]. However, a study comprising only pediatric patients reported lower complete response rate (24\%) [34]. In that study MSCs were cultured in platelet lysatecontaining medium, which may be associated with the inferior result. A study for adult patients using MSCs cultured in platelet lysatecontaining medium also showed poor response (CR rate; 8\%) [31]. Further studies are needed to clarify the superiority of MSC therapy in children. Acute toxicity related with MSC infusion was extremely rare in all the study. In contrast, infectious episodes were reported during the long term observation. Because the existence of severe acute GVHD itself contributes to compromised condition, the direct contribution of MSC therapy to frequency of infectious diseases needs to be evaluated in the future.

\section{Industrial MSC therapy for acute GVHD}

Osiris therapeutics, Inc. developed industrial mesenchymal cells derived from third-party bone marrow donors, Prochymal, as the world's first cell therapy drug. MSCs that are culture-expanded for 5 passages are cryopreserved as product lots. The cells are thawed and diluted before administration. Kebriaei et al. reported the first randomized, multicenter phase II trial of Prochymal for acute GVHD in 2009 [38]. In the study, Prochymal was administered at two different dose $(2$ or $8 \times 106$ cells $/ \mathrm{kg})$ with corticosteroid as the first line therapy to the patients with grade II-IV acute GVHD and the overall response rate was $93 \%$ (CR, 77\%; PR, 16\%). Subsequently, several studies of manufactured MSC therapy for steroid-resistant refractory acute GVHD have been reported (summarized in Table 2) [39-44]. CR and 
Citation: Yoshioka S, Miura Y (2016) Human Mesenchymal Stem Cell Therapy for Acute Graft Versus Host Disease. Transl Med (Sunnyvale) 6:

Page 3 of 6

overall response rate were $24-58 \%$ and $60-93 \%$, which were similar to the results of MSC therapy from individual donors. However, the median number doses for a treatment of manufactured MSC therapy was more than 8 , which was so many compared to individual MSC therapy. In addition, there was no significant difference of CR rate between Prochymal group and placebo group in a double-blind placebo-controlled randomized phase III trial $(40 \%$ and $28 \%, \mathrm{p}=0.08)$ [39]. On the other hand, in a small prospective, open-label, nonrandomized, multicenter study, CR rate in patients using MSCs in combination with conventional therapies for refractory acute GVHD was significantly higher than that in patients treated with only conventional therapies ( $61 \%$ and $26 \%, p=0.02)$ [43]. Prochymal has been approved in Canada and New Zealand as a treatment for steroidresistant refractory acute GVHD only in children. Another MSC drug, Temcell HS, which is manufactured according to Prochymal $[41,44]$, was recently approved for refractory acute GVHD in both adults and children in Japan. However, further experience is required to make a definitive assessment of these MSC drugs.

\begin{tabular}{|c|c|c|c|c|c|c|c|}
\hline Reference & $\begin{array}{l}\text { No. of } \\
\text { patients }\end{array}$ & $\begin{array}{l}\text { Median age of } \\
\text { patients (years) }\end{array}$ & MSC donor & $\begin{array}{l}\text { Median MSC dose } \\
\left(\times 10^{6} / \mathrm{kg}\right)\end{array}$ & $\begin{array}{l}\text { Number of } \\
\text { infusion (median) }\end{array}$ & CR (\%) & $\begin{array}{l}\text { CR+PR } \\
(\%)\end{array}$ \\
\hline Ringden et al. (30) & 8 & 56 & MSD (2), haplo (3), third party (3) & 1 & $1(1)$ & 63 & 63 \\
\hline Le Blanc et al. (29) & 55 & 22 & MSD (5), haplo (18), third party (69) & 1.4 & $1-5(2)$ & 55 & 71 \\
\hline von Bonin et al. (31) & 13 & 58 & Third party & 0.9 & $1-5(2)$ & 8 & 16 \\
\hline Lucchini et al. (32) & 11 & 10 & Third party & 1.2 & $1-5$ (NA) & 24 & 73 \\
\hline Herrmann et al. (33) & 12 & 48.5 & $\begin{array}{l}\text { MSD (1), mismached sibling (1), third } \\
\text { party (10) }\end{array}$ & $1.7-2.3$ & 2-19 (2) & 58 & 33 \\
\hline Resnick et al. (35) & 50 & 19 & $\begin{array}{l}\text { The same donor as HSC donor (7), } \\
\text { third party (67) }\end{array}$ & 1.1 & $1-4(\mathrm{NA})$ & 34 & 66 \\
\hline Ball et al. (34) & 37 & 7 & Haplo (3), third party (34) & 2 & $1-13(2)$ & 65 & 86 \\
\hline Introna et al. (36) & 31 & NA & Third party & 1.5 & $2-11(3)$ & 29 & 74 \\
\hline $\begin{array}{l}\text { Sanchez-Guijo et al. } \\
\text { (37) }\end{array}$ & 25 & NA & Third party & 1.1 & $2-4(4)$ & 46 & 71 \\
\hline
\end{tabular}

Table 1: Summary of MSC therapy for steroid-resistant acute GVHD using individual MSC donors. MSD: HLA-matched sibling donor, haplo: HLA-haploidentical donor, NA: data not available.

\begin{tabular}{|c|c|c|c|c|c|c|c|}
\hline Reference & Study type & No. of patients & Median age of patients (years) & $\begin{array}{l}\text { Median MSC } \\
\text { dose }\left(\times 10^{6} / \mathrm{kg}\right)\end{array}$ & $\begin{array}{l}\text { Number } \\
\text { (median) }\end{array}$ of infusions & CR (\%) & $\begin{array}{l}\text { CR+PR } \\
(\%)\end{array}$ \\
\hline Prasad et al. (40) & Phase I/II & 12 & 5 & 2 or 8 & $2-21(8.5)$ & 58 & 75 \\
\hline Muroi et al. (41) & Phase I/II & 14 & 52 & 2 & 3-12 (8) & 57 & 93 \\
\hline \multirow[t]{2}{*}{$\begin{array}{l}\text { P. J. Martin et al. } \\
\text { (39) }\end{array}$} & Phase III & 163 (Prochymal $\circledast$ ) & NA & 2 & 8 & 40 & 82 \\
\hline & & 81 (placebo) & NA & & & 28 & 73 \\
\hline $\begin{array}{l}\text { Kurtzberg et al. } \\
(42)\end{array}$ & Phase III & 75 & 7.8 & 2 & $1-20(10)$ & NA & 61.3 \\
\hline Muroi et al. (44) & Phase II/III & 25 & 33 & 2 & $4-8(8)$ & 24 & 60 \\
\hline \multirow[t]{2}{*}{ Zao et al. (43) } & $\begin{array}{l}\text { Open-label } \\
\text { non- } \\
\text { randomized }\end{array}$ & 28 (MSC+) & 26 & 1 & $2-8(4)$ & 61 & 75 \\
\hline & & 19 (MSC-) & 29 & & & 26 & 42 \\
\hline
\end{tabular}

Table 2: Summary of MSC therapy for steroid-resistant acute GVHD using manufactured MSCs. NA: data not available.

\section{MSC for acute GVHD prophylaxis}

Recently, some researchers attempt to utilize MSCs derived from the same donors as hematopoietic stem cell (HSC) donors for prophylaxis of acute GVHD. Shinpounova et al. conducted a randomized trial to examine the efficacy of MSC therapy on acute GVHD prophylaxis [45]. Authors compared 39 patients received MSC therapy for acute GHVD prophylaxis with 38 patients received standard GVHD prophylaxis. In the study, MSCs were administered the day when peripheral leukocyte count reached $109 / \mathrm{L}$ at a median dose of $1.2 \times 106$ cells $/ \mathrm{kg}$ (range, $0.9-1.65 \times 106$ cells $/ \mathrm{kg}$ ). The incidence of acute GVHD with grade IIIV were significantly decreased in the MSC prophylaxis group compared to the standard prophylaxis group (9.4\% versus $29.4 \%, \mathrm{p}=$ 
Citation: Yoshioka S, Miura Y (2016) Human Mesenchymal Stem Cell Therapy for Acute Graft Versus Host Disease. Transl Med (Sunnyvale) 6:

0.041). There was no significant difference in donor characteristics and MSC's properties between two groups. Gene expression profile analysis in MSCs suggested that increased gene expression of fibroblast growth factor receptor 1 (FGFR1) and platelet-derived growth factor receptor beta (PDGFRB) in MSCs might be related with decrease of the incidence of acute GVHD. Maziarz et al. conducted phase I dose escalation study to evaluate the availability and the safety of an industrial MSC, "allogeneic multipotent adult progenitor cell (MAPC) (MultiStem, Athersys, Inc., Cleveland, OH)" for acute GVHD prophylaxis [46]. Authors compared the efficacy of a single dose injection of MAPC $(1,5$, or $10 \times 106$ cells $/ \mathrm{kg}, \mathrm{n}=18)$ with that of once a week multiple dose injection of MAPC $(1$ or $5 \times 106$ cells $/ \mathrm{kg}, \mathrm{n}=18)$. No infusion-related toxicities were observed, but 3 patients had a possible dose-limiting toxicity (DLT) event, within 30 days of MAPC administration: grade 3 mucositis, grade 3 hypoxic respiratory failure and grade 3 renal failure, and grade 4 hyperbilirubinemia. Enough attention to adverse effects should be taken when a high dose of MAPC administered. There were no differences in GVHD frequency between the single-dose arm and the multiple-dose arm in this study. The usage of MSCs for acute GVHD prophylaxis should be carefully considered.

\section{Problems and future directions of MSC therapy for acute GVHD}

There is room for improvement on MSC therapy for refractory acute GVHD. The quality assurance of MSCs is the most important problem. As described above, the requirement of repeated administration in industrial MSC therapy probably could arise from their dysfunction induced by bulk production. Von Bahr et al. reported that the patients who received MSCs from passage 1-2 have better survival (75\% at 1 year) than those who receive MSCs from passage 3-4 $(21 \%)(\mathrm{p}<0.01)$ [47]. In addition, the immune plasticity of MSCs may vary depending on donors. Many donors are required to secure the quality and quantity of MSCs. The usage of alternative source, like cord blood (CB) [48, 49], Wharton's jelly cells (WJCs) [50], adipose tissue [51], teeth [52,53], could be one of solutions. Especially, CB and WJCs are obtainable at delivery without invasive procedure unlike bone marrow and are/ supposed to be waste materials unless used as a source of HSCs. In addition, MSCs derived from them have better proliferation potential than BM-MSCs. These could be strong candidates of alternative sources of MSCs. There are only a few small pilot studies of MSC therapy using an alternative source for refractory acute GVHD [54,55]. In the near future, embryonic stem cells [56] and induced pluripotent stem cells [57] could be available for MSC source. The usage of alternative sources is experimental and further studies are needed for practical clinical applications. In addition, the superiority of these third donor MSCs to HLA matched donor in MSC therapy has yet to be elucidated.

MSC therapy has few acute adverse effects but its immunosuppressive effect may provoke several problems: disease relapse and susceptibility to infection. Zhao et al. reported that there is no significant difference in tumor relapse rate, cytomegalovirus (CMV) and Epstein-Barr virus (EBV) infections between MSC-treated group and MSC-untreated group in which enrolled patients were divided by the voluntary principle [43]. Calkoen et al. reported that only adenovirus infection (ADV) was associated with poor prognosis in children treated with MSCs although the incidence of CMV, EBV, and ADV infection was not significantly increased [58]. The authors indicated that virus-specific $\mathrm{T}$ cell activation and proliferation were impaired by MSC therapy. We need to devote enough attention to viral infection.

MSC therapy for refractory acute GVHD has been conducted in many countries because of its attractive results, but there are many issues to be investigated: cell dose, cell source, culture condition, quality, long term effect, and late complications. MSC therapy is still on the way to be established and should be used appropriately in clinical setting now. Future progress would contribute to establish MSC therapy as is the case with HSCT.

\section{References}

1. Arnaout K, Patel N, Jain M, El-Amm J, Amro F, et al. (2014) Complications of allogeneic hematopoietic stem cell transplantation. Cancer Invest 32: 349-362.

2. Pavletic SZ, Fowler DH (2012) Are we making progress in GVHD prophylaxis and treatment? Hematology Am Soc Hematol Educ Program 2012: 251-264

3. Martin PJ, Rizzo JD, Wingard JR, Ballen K, Curtin PT, et al. (2012) Firstand second-line systemic treatment of acute graft-versus-host disease: recommendations of the american society of blood and marrow transplantation. Biol Blood Marrow Transplant 18:1150-1163.

4. Friedenstein AJ, Petrakova KV, Kurolesova AI, Frolova GP (1968) Heterotopic of bone marrow. Analysis of precursor cells for osteogenic and hematopoietic tissues. Transplantation 6: 230-247.

5. Pittenger MF, Mackay AM, Beck SC, Jaiswal RK, Douglas R, et al. (1999) Multilineage potential of adult human mesenchymal stem cells. Science 284: 143-147.

6. Dominici M, Le Blanc K, Mueller I, Slaper-Cortenbach I, Marini F, et al. (2006) Minimal criteria for defining multipotent mesenchymal stromal cells. The International Society for Cellular Therapy position statement. Cytotherapy 8: 315-317.

7. Mendelson A, Frenette PS (2014) Hematopoietic stem cell niche maintenance during homeostasis and regeneration. Nat Med 20: 833-846.

8. Morrison SJ, Scadden DT (2014) The bone marrow niche for haematopoietic stem cells. Nature 505: 327-334.

9. Bailey AM (2012) Balancing tissue and tumor formation in regenerative medicine. Sci Transl Med 4: 147fs28.

10. Liechty KW, MacKenzie TC, Shaaban AF, Radu A, Moseley AM, et al. (2000) Human mesenchymal stem cells engraft and demonstrate sitespecific differentiation after in utero transplantation in sheep. Nat Med 6: 1282-1286.

11. Shi M, Liu ZW, Wang FS (2011) Immunomodulatory properties and therapeutic application of mesenchymal stem cells. Clin Exp Immunol 164: 1-8.

12. Gebler A, Zabel O, Seliger B (2012) The immunomodulatory capacity of mesenchymal stem cells. Trends Mol Med 18: 128-134.

13. Le Blanc K, Mougiakakos D (2012) Multipotent mesenchymal stromal cells and the innate immune system. Nat Rev Immunol 12: 383-396.

14. Gao F, Chiu SM, Motan DA, Zhang Z, Chen L, et al. (2016) Mesenchymal stem cells and immunomodulation: current status and future prospects. Cell Death Dis 7: e2062.

15. Di Nicola M, Carlo-Stella C, Magni M, Milanesi M, Longoni PD, et al. (2002) Human bone marrow stromal cells suppress T-lymphocyte proliferation induced by cellular or nonspecific mitogenic stimuli. Blood 99: 3838-3843.

16. Tse WT, Pendleton JD, Beyer WM, Egalka MC, Guinan EC (2003) Suppression of allogeneic T-cell proliferation by human marrow stromal cells: implications in transplantation. Transplantation 75: 389-397.

17. Glennie S, Soeiro I, Dyson PJ, Lam EW, Dazzi F (2005) Bone marrow mesenchymal stem cells induce division arrest anergy of activated T cells. Blood 105: 2821-2827.

18. Ghannam S, Pène J, Moquet-Torcy G, Jorgensen C, Yssel H (2010) Mesenchymal stem cells inhibit human Th17 cell differentiation and 
Citation: Yoshioka S, Miura Y (2016) Human Mesenchymal Stem Cell Therapy for Acute Graft Versus Host Disease. Transl Med (Sunnyvale) 6:

Page 5 of 6

function and induce a $\mathrm{T}$ regulatory cell phenotype. J Immunol 185 302-312.

19. Maccario R, Podesta M, Moretta A, Cometa A, Comoli P, et al. (2005) Interaction of human mesenchymal stem cells with cells involved in alloantigen-specific immune response favors the differentiation of CD4+ T-cell subsets expressing a regulatory/suppressive phenotype. Haematologica 90: 516-525.

20. Sotiropoulou PA, Perez SA, Gritzapis AD, Baxevanis CN, Papamichail M (2006) Interactions between human mesenchymal stem cells and natural killer cells. Stem Cells 24: 74-85.

21. Corcione A, Benvenuto F, Ferretti E, Giunti D, Cappiello V, et al. (2006) Human mesenchymal stem cells modulate B-cell functions. Blood 107: 367-372.

22. Jiang XX, Zhang Y, Liu B, Zhang SX, Wu Y, et al. (2005) Human mesenchymal stem cells inhibit differentiation and function of monocytederived dendritic cells. Blood 105: 4120-4126.

23. Krampera M, Cosmi L, Angeli R, Pasini A, Liotta F, et al. (2006) Role for interferon-gamma in the immunomodulatory activity of human bone marrow mesenchymal stem cells. Stem Cells 24: 386-398.

24. Pevsner-Fischer M, Morad V, Cohen-Sfady M, Rousso-Noori L, ZaninZhorov A, et al. (2007) Toll-like receptors and their ligands control mesenchymal stem cell functions. Blood 109: 1422-1432.

25. Le Blanc K, Tammik L, Sundberg B, Haynesworth SE, Ringden O (2003) Mesenchymal stem cells inhibit and stimulate mixed lymphocyte cultures and mitogenic responses independently of the major histocompatibility complex. Scand J Immunol 57: 11-20.

26. Ankrum JA, Ong JF, Karp JM (2014) Mesenchymal stem cells: immune evasive, not immune privileged. Nat Biotechnol 32: 252-260.

27. Miura Y, Yoshioka S, Yao H, Takaori-Kondo A, Maekawa T, et al. (2013) Chimerism of bone marrow mesenchymal stem/stromal cells in allogeneic hematopoietic cell transplantation: is it clinically relevant? Chimerism 4: 78-83.

28. Le Blanc K, Rasmusson I, Sundberg B, Gotherstrom C, Hassan M, et al. (2004) Treatment of severe acute graft-versus-host disease with third party haploidentical mesenchymal stem cells. Lancet 363: 1439-1441.

29. Le Blanc K, Frassoni F, Ball L, Locatelli F, Roelofs H, et al. (2008) Mesenchymal stem cells for treatment of steroid-resistant, severe, acute graft-versus-host disease: a phase II study. Lancet 371: 1579-1586.

30. Ringdén O, Uzunel M, Rasmusson I, Remberger M, Sundberg B, et al (2006) Mesenchymal stem cells for treatment of therapy-resistant graftversus-host disease. Transplantation 81: 1390-1397.

31. von Bonin M, Stölzel F, Goedecke A, Richter K, Wuschek N, et al. (2009) Treatment of refractory acute GVHD with third-party MSC expanded in platelet lysate-containing medium. Bone Marrow Transplant 43: 245-251.

32. Lucchini G, Introna M, Dander E, Rovelli A, Balduzzi A, et al. (2010) Platelet-lysate-expanded mesenchymal stromal cells as a salvage therapy for severe resistant graft-versus-host disease in a pediatric population. Biol Blood Marrow Transplant 16: 1293-1301.

33. Herrmann R, Sturm M, Shaw K, Purtill D, Cooney J, et al. (2012) Mesenchymal stromal cell therapy for steroid-refractory acute and chronic graft versus host disease: a phase 1 study. International journal of hematology 95: 182-188.

34. Ball LM, Bernardo ME, Roelofs H, van Tol MJ, Contoli B, et al. (2013) Multiple infusions of mesenchymal stromal cells induce sustained remission in children with steroid-refractory, grade III-IV acute graftversus-host disease. Br J Haematol 163: 501-509.

35. Resnick IB, Barkats C, Shapira MY, Stepensky P, Bloom AI, et al. (2013) Treatment of severe steroid resistant acute GVHD with mesenchymal stromal cells (MSC). Am J Blood Res 3: 225-238.

36. Introna M, Lucchini G, Dander E, Galimberti S, Rovelli A, et al. (2014) Treatment of graft versus host disease with mesenchymal stromal cells: a phase I study on 40 adult and pediatric patients. Biol Blood Marrow Transplant 20: 375-381.

37. Sanchez-Guijo F, Caballero-Velazquez T, Lopez-Villar O, Redondo A Parody R, et al. (2014) Sequential third-party mesenchymal stromal cell therapy for refractory acute graft-versus-host disease. Biol Blood Marrow Transplant 20: 1580-1585.

38. Kebriaei P, Isola L, Bahceci E, Holland K, Rowley S, et al. (2009) Adult human mesenchymal stem cells added to corticosteroid therapy for the treatment of acute graft-versus-host disease. Biol Blood Marrow Transplant 15: 804-811.

39. Martin PJ, Uberti JP, Soiffer RJ, Klingemann H, Waller EK, et al. (2010) Prochymal improves response rates in patients with Steroid-Refractory Acute Graft Versus Host Disease (SR-GVHD) involving the liver and gut: results of a randomized, placebo-controlled, multicenter phase III trial in GVHD. Biol Blood Marrow Transplant 16: S169-S170.

40. Prasad VK, Lucas KG, Kleiner GI, Talano JA, Jacobsohn D, et al. (2011) Efficacy and safety of ex vivo cultured adult human mesenchymal stem cells (Prochymal) in pediatric patients with severe refractory acute graftversus-host disease in a compassionate use study. Biol Blood Marrow Transplant 17: 534-541.

41. Muroi K, Miyamura K, Ohashi K, Murata M, Eto T, et al. (2013) Unrelated allogeneic bone marrow-derived mesenchymal stem cells for steroid-refractory acute graft-versus-host disease: a phase I/II study. Int J Hematol 98: 206-213.

42. Kurtzberg J, Prockop S, Teira P, Bittencourt H, Lewis V, et al. (2014) Allogeneic human mesenchymal stem cell therapy (remestemcel-L, Prochymal) as a rescue agent for severe refractory acute graft-versus-host disease in pediatric patients. Biol Blood Marrow Transplant 20: 229-235.

43. Zhao K, Lou R, Huang F, Peng Y, Jiang Z, et al. (2015) Immunomodulation effects of mesenchymal stromal cells on acute graftversus-host disease after hematopoietic stem cell transplantation. Biol Blood Marrow Transplant 21: 97-104.

44. Muroi K, Miyamura K, Okada M, Yamashita T, Murata M, et al. (2016) Bone marrow-derived mesenchymal stem cells (JR-031) for steroidrefractory grade III or IV acute graft-versus-host disease: a phase II/III study. Int J Hematol 103: 243-250.

45. Shipounova IN, Petinati NA, Bigildeev AE, Zezina EA, Drize NI, et al. (2014) Analysis of results of acute graft-versus-host disease prophylaxis with donor multipotent mesenchymal stromal cells in patients with hemoblastoses after allogeneic bone marrow transplantation. Biochemistry (Mosc) 79: 1363-1370.

46. Maziarz RT, Devos T, Bachier CR, Goldstein SC, Leis JF, et al. (2015) Single and multiple dose MultiStem (multipotent adult progenitor cell) therapy prophylaxis of acute graft-versus-host disease in myeloablative allogeneic hematopoietic cell transplantation: a phase 1 trial. Biol Blood Marrow Transplant 21: 720-728.

47. von Bahr L, Sundberg B, Lonnies L, Sander B, Karbach H, et al. (2012) Long-term complications, immunologic effects, and role of passage for outcome in mesenchymal stromal cell therapy. Biol Blood Marrow Transplant 18: 557-564.

48. Zhang X, Hirai M, Cantero S, Ciubotariu R, Dobrila L, et al. (2011) Isolation and characterization of mesenchymal stem cells from human umbilical cord blood: reevaluation of critical factors for successful isolation and high ability to proliferate and differentiate to chondrocytes as compared to mesenchymal stem cells from bone marrow and adipose tissue. J Cell Biochem 112: 1206-1218.

49. Yoshioka S, Miura Y, Iwasa M, Fujishiro A, Yao H, et al. (2015) Isolation of mesenchymal stromal/stem cells from small-volume umbilical cord blood units that do not qualify for the banking system. Int J Hematol 102: 218-229

50. Troyer DL, Weiss ML (2008) Wharton's jelly-derived cells are a primitive stromal cell population. Stem Cells 26: 591-599.

51. Zuk PA, Zhu M, Ashjian P, De Ugarte DA, Huang JI, et al. (2002) Human adipose tissue is a source of multipotent stem cells. Mol Biol Cell 13: 4279-4295.

52. Gronthos S, Mankani M, Brahim J, Robey PG, Shi S (2000) Postnatal human dental pulp stem cells (DPSCs) in vitro and in vivo. Proc Natl Acad Sci U S A 97: 13625-13630. 
Citation: Yoshioka S, Miura Y (2016) Human Mesenchymal Stem Cell Therapy for Acute Graft Versus Host Disease. Transl Med (Sunnyvale) 6:

53. Miura M, Gronthos S, Zhao M, Lu B, Fisher LW, et al. (2003) SHED: stem cells from human exfoliated deciduous teeth. Proc Natl Acad Sci USA 100: 5807-5812.

54. Fang B, Song Y, Liao L, Zhang Y, Zhao RC (2007) Favorable response to human adipose tissue-derived mesenchymal stem cells in steroidrefractory acute graft-versus-host disease. Transplant Proc 39: 3358-3362.

55. Wu KH, Chan CK, Tsai C, Chang YH, Sieber M, et al. (2011) Effective treatment of severe steroid-resistant acute graft-versus-host disease with umbilical cord-derived mesenchymal stem cells. Transplantation 91: 1412-1416.

56. Trivedi P, Hematti P (2008) Derivation and immunological characterization of mesenchymal stromal cells from human embryonic stem cells. Exp Hematol 36: 350-359.
57. Koyama N, Miura M, Nakao K, Kondo E, Fujii T, et al. (2013) Human induced pluripotent stem cells differentiated into chondrogenic lineage via generation of mesenchymal progenitor cells. Stem Cells Dev 22: 102-113.

58. Calkoen FG, Vervat C, van Halteren AG, Welters MJ, Veltrop-Duits LA, et al. (2014) Mesenchymal stromal cell therapy is associated with increased adenovirus-associated but not cytomegalovirus-associated mortality in children with severe acute graft-versus-host disease. Stem Cells Transl Med 3: 899-910. 